\title{
Analisis Tingkat Kepuasan Pengguna E-Learning Universitas Telkom Menggunakan Metode End-User Computing Satisfaction
}

\author{
Khansa' Nadhifah Rabbaniah Al Habsyi*1, Berlian Maulidya Izzati ${ }^{3}$, Muhardi Saputra ${ }^{3}$ \\ ${ }^{1,2,3}$ Program Studi Sistem Informasi, Universitas Telkom; Jl. Telekomunikasi Terusan Buah \\ Batu Bandung 40257, Telp (022) 7566456 \\ e-mail: *11 khansaalhabsyi@ student.telkomuniversity.ac.id, ${ }^{3}$ berlianmi@ @elkomuniversity.ac.id, \\ 33uhardi@telkomuniversity.ac.id
}

\begin{abstract}
Abstrak
Pesatnya perkembangan teknologi informasi ditambah dengan adanya pandemi COVID19 yang merabah di masyarakat membuat seluruh kegiatan dialihkan ke media online termasuk perkuliahan di Universitas Telkom. Media sistem informasi e-learning yang digunakan adalah CeLOE LMS yang ditujukan untuk mendukung sebagian besar kegiatan perkuliahan online bagi mahasiswa selama Pembelajaran Jarak Jauh (PJJ) dilaksanakan. Dalam penerapan CeLOE LMS ini banyak sekali perubahan dari awal perkuliahan online hingga sekarang, namun pihak manajemen CeLOE LMS sendiri belum pernah melakukan penelitian atau evaluasi terkait kepuasan menggunakan CeLOE LMS, untuk itu perlu adanya penelitian yang berkaitan dengan hal ini untuk menilai bahwa sistem yang diterapkan sangat mempermudah pengguna sesuai dengan kebutuhan dari segi konten, keakuratan informasi yang diberikan, kemudahan dalam penggunaan, tampilan interface, serta ketepatan waktu dalam penyajian informasi. Penelitian ini menggunakan teknik purposive sampling dengan menyebarkan kuesioner melalui beberapa platform media sosial. Model penelitian yang digunakan adalah End-User Computing Satisfaction (EUCS) dengan 6 variabel yang terlibat yaitu Content, Accuracy, Format, Ease of Use, Timeliness, dan End-User Satisfaction serta menggunakan analisis perhitungan menggunakan metode PLS-SEM dengan alat bantu SmartPLS versi 3.0. Sampel penelitian ini terdiri dari 205 responden mahasiswa aktif program studi strata satu Universitas Telkom dengan jumlah populasi 22279 mahasiswa. Hasil dari 5 hipotesis yang diajukan, terdapat 2 hipotesis yang ditolak karena hasil analisis t-statistics $>1,97$ yang artinya hubungan antara variabel Accuracy (ACC) dan variabel Format (FOR) tidak berpengaruh secara signifikan terhadap variabel End-User Satisfaction (EUS).
\end{abstract}

Kata kunci-CeLOE LMS, Pembelajaran Jarak Jauh, End-User Computing Satisfaction, PLSSEM, Adopsi IT

\begin{abstract}
The rapid development of information technology, especially due to the COVID-19 pandemic that has spread in the community, has shifted all activities to online media including lectures at Telkom University. The e-learning information system media used is CeLOE LMS where this system is intended to support most of the online lecture activities for students during distance learning. The use of the CeLOE LMS has changed a lot from the beginning of online lectures until now, but the management of CeLOE LMS itself has never conducted research or evaluation related to satisfaction of using CeLOE LMS, it is necessary to have research related to this matter to assess the system implemented makes it easier for users according to their needs in terms of content, the accuracy of the information provided, ease of use, interface display, and timeliness in presenting the information. This research uses purposive sampling technique by distributing questionnaires through several social media platforms. The research
\end{abstract}


model used is End-User Computing Satisfaction (EUCS) with 6 variables involved, namely Content, Accuracy, Format, Ease of Use, Timeliness, and End-User Satisfaction using calculation analysis PLS-SEM method with SmartPLS version 3.0 tools. The sample of this research consisted of 205 respondents of active students of Telkom University undergraduate study program with a total population of 22279 students. The results of the 5 proposed hypotheses, there are 2 hypotheses that are rejected because the results of $t$-statistics analysis $>1,97$ which means that the relationship between the Accuracy (ACC) variable and the Format (FOR) variable does not significantly effect the End-User Computing Satisfaction (EUS) variable.

Keywords-CeLOE LMS, Distance Learning, End-User Computing Satisfaction, PLS-SEM, IT Adoption

\section{PENDAHULUAN}

$\mathrm{D}$ unia dilanda dengan musibah penyebab infeksi yang belum diketahui pada awal tahun 2020, yang diawali dari laporan negara Cina kepada World Health Organization (WHO) terdapat 44 pasien pneumonia yang berat diakhir tahun 2019 tepatnya berada di kota Wuhan, China. Asumsi awal akan terjadinya hal ini berkaitan dengan pasar yang menjual hewan laut dan berbagai hewan lain. Penyebabnya mulai teridentifikasi dan didapatkan kode genetiknya yaitu virus corona baru pada awal tahun, tepatnya pada tanggal 10 Januari 2020 [1]. Salah satu negara yang terkena dampak dari virus COVID-19 adalah negara Indonesia. Akibatnya, pemerintah Indonesia mengeluarkan kebijakan untuk melakukan karantina bagi masyarakat agar segala aktivitas dilakukan dari rumah secara online, melakukan social distancing apabila sedang berada diluar rumah untuk hal yang mendesak, dan tetap mengikuti aturan protokol kesehatan agar dapat memutus tali penyebaran virus COVID-19. Sehingga, semua aktivitas yang berkaitan dengan kegiatan belajar mengajar jadi terhenti sementara dan kemudian dialihkan dengan menggunakan sistem pembelajaran online dengan memanfaatkan teknologi informasi.

Pesatnya perkembangan teknologi saat ini memiliki dampak yang sangat besar dan global dalam berbagai aspek kehidupan termasuk dalam bidang pendidikan. Mudahnya akses terhadap internet dan teknologi informasi membuat banyak developer yang mengembangkan web ataupun aplikasi yang membantu untuk menunjang kegiatan belajar mengajar dengan berbagai model. Salah satu yang digunakan di Universitas Telkom adalah Center for e-Learning \& Open Education Learning Management System (CeLOE LMS) yang merupakan sebuah platform untuk mendukung proses belajar mahasiswa secara online. Pada sistem LMS, user dapat melakukan interaksi satu sama lain, dan melakukan akses berbagai macam aktivitas yang berkaitan dengan perkuliahan seperti tutorial, materi pembelajaran, submit tugas, quiz, dll. guna memenuhi capaian pembelajaran.

Dengan adanya peran teknologi untuk dapat menunjang kegiatan pembelajaran yang berkualitas baik memerlukan perencanaan yang sangat matang dan sistematik. Pergantian media pembelajaran dari offline ke media online menjadi inovasi dalam kondisi lingkungan global, dan tanpa dibatasi dengan adanya unsur tempat [2]. Penggunaan teknologi dalam pendidikan, umumnya didefinisikan sebagai e-learning. Aplikasi teknologi tidak terbatas pada ruang kelas, mereka juga menempatkan beberapa sesi kelas dengan sesi virtual atau sepenuhnya mengganti kelas offline dengan kelas online [3]. Berdasarkan Undang-Undang tentang Pendidikan Tinggi Nomor 12 Tahun 2012 Pasal 31 tentang Pendidikan Jarak Jauh ayat (1) yang berbunyi "Pendidikan jarak jauh merupakan proses belajar mengajar yang dilakukan secara jarak jauh

$\mathrm{Al}$ Habsyi, et al., [Analisis Tingkat Kepuasan Pengguna E-Learning Universitas Telkom Menggunakan Metode End-User Computing Satisfaction 
melalui penggunaan berbagai media komunikasi". Dan Pasal 31 ayat (2) yang berbunyi "Pendidikan jarak jauh sebagaimana yang dimaksud pada ayat (1) memberikan layanan Pendidikan Tinggi kepada kelompok Masyarakat yang tidak dapat mengikuti pendidikan secara tatap muka atau reguler, dan memperluas akses serta mempermudah layanan Pendidikan Tinggi dalam Pendidikan dan pembelajaran". Adopsi teknologi informasi juga menjadi salah satu faktor penting suatu instansi dalam rangka mencapai tujuan pembelajaran yang efektif dan efisien dengan menggabungkan sumber daya instansi yang dimiliki agar input dan output-nya seimbang [4].

Metode yang digunakan dalam penelitian ini yaitu End-User Computing Satisfaction (EUCS) untuk mengukur tingkat kepuasan user dengan memperkirakan antara ekspektasi dan realita yang terjadi pada media sistem informasi [5]. Metode EUCS ini dapat mengukur tingkat kepuasan mahasiswa yang akan menjadi pertimbangan dalam melakukan pengambilan keputusan terhadap output sistem pembelajaran online, karena tingkat kepuasan mahasiswa yang menerapkan e-learning bisa menjadi cerminan mutu dari pembelajaran online. Indikator yang digunakan untuk mengukur kepuasan mahasiswa adalah Content, Accuracy, Format, Ease of Use, Timeliness [6]. Alasan mengapa menggunakan metode EUCS adalah karena pada penelitian yang telah dilakukan sebelumnya, metode ini terbukti apabila terdapat variasi bahasa yang digunakan, tidak ada disimilaritas secara signifikan, dan telah teruji kredibilitasnya [7].

Perhitungan analisis pada penelitian ini adalah metode Structural Equation Modeling (SEM) dimana metode ini merupakan analisis statistik inferensial yang difokuskan dalam melakukan analisis dan interpretasi data untuk kemudian membuat kesimpulan, dan dengan bantuan software SmartPLS akan menjadi lebih mudah dan singkat dalam melakukan pengolahan data [8]. Metode analisis Partial Least Square (PLS) dinilai dapat digunakan pada jenis pemodelan indikator yang bersifat reflektif atau formatif, jumlah hipotesa yang sedikit, dan skala data yang jumlahnya relatif tidak selalu besar [9]. PLS adalah analisis persamaan struktural yang terbilang powerful karena tidak didasarkan pada asumsi berdistribusi normal, dan ukuran sampel tidak harus besar.

Penelitian ini bertujuan untuk melakukan analisis terhadap tingkat kepuasan pengguna $e$ learning CeLOE LMS dengan menggunakan metode End-User Computing Satisfaction di Universitas Telkom sehingga dapat dijadikan sebagai pengukuran atau bahan evaluasi bagi pengelola CeLOE LMS untuk dikembangkan menjadi sistem yang lebih baik lagi. 


\section{METODE PENELITIAN}

\subsection{Sistematika Penelitian}

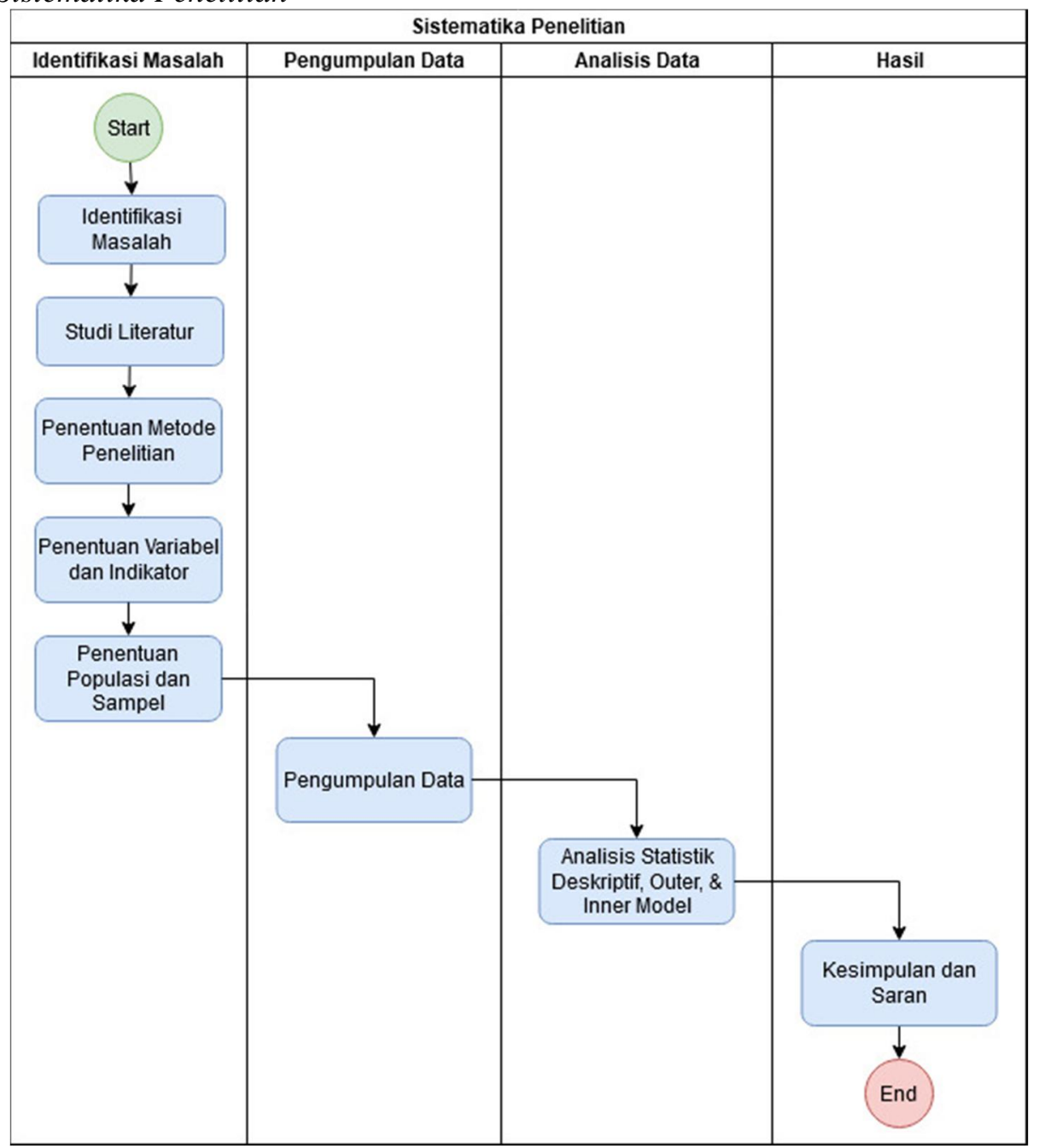

Gambar 1. Sistematika Penelitian

1) Identifikasi masalah, melakukan identifikasi atau pengenalan terhadap permasalahan yang terjadi untuk dijadikan topik penelitian yang menjadi langkah pertama dalam melakukan penelitian.

2) Studi literatur, mencari sebanyak mungkin referensi penelitian terdahulu untuk dijadikan acuan dalam mengerjakan penelitian, dan landasan teori dari berbagai sumber untuk menjadi bukti bahwa penelitian yang dilakukan berdasarkan data ataupun teori yang aktual dan terpercaya.

3) Penentuan metode penelitian, menentukan metode atau model penelitian yang menjadi suatu kegiatan ilmiah untuk mendapatkan informasi agar tercapainya tujuan pemecahan masalah dengan cara yang terstruktur [10].

4) Penentuan variabel dan indikator, menentukan variabel untuk dijadikan fokus penelitian dari setiap objek atau subjek yang digunakan untuk menjawab hal-hal yang menjadi permasalahan penelitian yang juga menjadi atribut atau bidang keilmuan tertentu [10]. 
Sedangkan, indikator merupakan bagian dari variabel yang digunakan untuk menguatkan variabel untuk memperoleh informasi dari objek penelitian.

5) Penentuan populasi dan sampel, dimana populasi menurut [10] merupakan keseluruhan bagian yang terdiri dari objek atau subjek yang memiliki karakteristik tertentu, sedangkan sampel merupakan bagian dari populasi objek atau subjek yang diteliti dengan hasil untuk mewakili keseluruhan populasi. Penelitian ini melibatkan mahasiswa aktif strata satu Universitas Telkom sebagai populasi penelitian dengan jumlah 22279 orang. Hal ini dikarenakan dari semua stakeholder yang terlibat dalam penggunaan CeLOE LMS, yang cenderung mudah dijangkau dengan pendekatan yang lebih mudah, dan keterlibatan interaksi secara intens dengan CeLOE LMS sesuai dengan pertimbangan yang telah ditentukan peneliti. Sehingga, penelitian ini menggunakan teknik purposive sampling dan perhitungan sampel menggunakan sample size.

6) Pengumpulan data, melakukan wawancara kepada pihak pengelola CeLOE LMS untuk mendapatkan informasi yang dapat dipertanggung jawabkan terkait sistem CeLOE LMS dan penggunaannya yang dialami selama masa pandemi, dan melalui penyebaran kuesioner dimana peneliti memberikan pertanyaan yang sudah ditetapkan berdasarkan indikator pada setiap variabel penelitian.

7) Analisis statistik deskriptif, melakukan analisis terhadap karakteristik dari masing-masing variabel dilihat dari nilai modus, maksimum, minimum, dan standard deviation.

8) Analisis Outer Model \& Inner Model, melakukan analisis evaluasi pengukuran model dimana didalamnya terdapat uji validitas yang dibagi menjadi convergent validity dan discriminant validity, uji reliabilitas yang dibagi menjadi cronbach's alpha dan composite reliability, serta evaluasi struktural model dimana didalamnya terdapat uji $R$-square, path coefficients, $t$-statistics, predictive relevance, dan model fit menggunakan software SmartPLS versi 3.

9) Kesimpulan dan saran, membuat ringkasan hasil penelitian dan poin penting dari keseluruhan proses, serta saran untuk dijadikan bahan evaluasi yang lebih baik lagi bagi instansi pendidikan maupun penelitian yang akan datang.

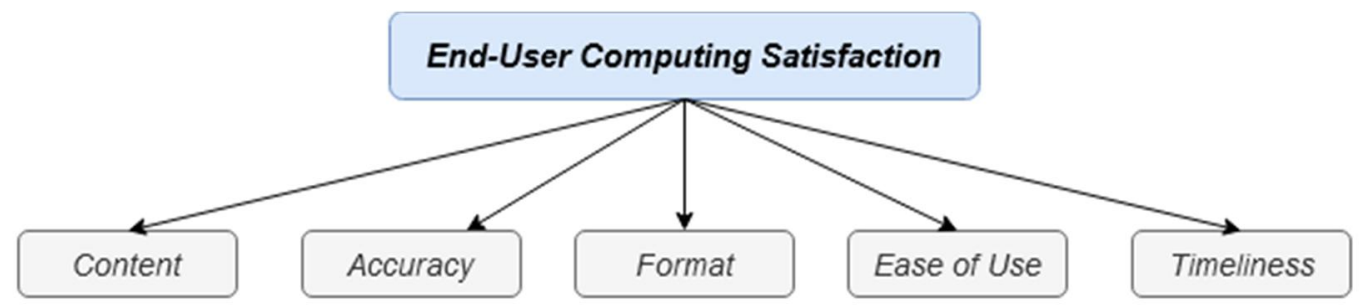

Gambar 2. Model Dasar EUCS

Metode penelitian End-User Computing Satisfaction (EUCS) yang digunakan terhadap sistem informasi untuk menganalisa tingkat kepuasan dari setiap user dengan membandingkan antara ekspektasi dengan realita [11]. Hal ini dilakukan dengan cara mengevaluasi secara keseluruhan yang terdiri dari 5 aspek variabel dari pengguna [5]. Indikator kepuasan menggunakan EUCS menurut [12], yaitu:

a. Content (Isi)

Melakukan pengukuran dilihat dari sisi konten fungsi sistem berupa informasi yang dihasilkan oleh sistem terhadap end-user satisfaction.

b. Accuracy (Akurasi) 
Melakukan pengukuran dari sisi keakuratan data ketika sistem menerima input kemudian diolah menjadi informasi terhadap end-user satisfaction.

c. Format (Bentuk)

Melakukan pengukuran dari sisi interface display, informasi yang dihasilkan, menarik dan memudahkan user terhadap end-user satisfaction.

d. Ease of Use (Kemudahan Pengguna)

Melakukan pengukuran dari sisi kemudahan pengguna dalam menggunakan sistem terhadap end-user satisfaction.

e. Timeliness (Ketepatan Waktu)

Melakukan pengukuran dari sisi ketepatan waktu sistem dalam menyajikan data dan informasi yang dibutuhkan terhadap end-user satisfaction.

\subsection{Skala Likert}

Skala likert merupakan pengukuran yang digunakan sebagai acuan untuk mengukur opini seseorang terhadap objek maupun subjek tertentu untuk menghasilkan data kuantitatif [10]. Informasi skala pengukuran yang digunakan disajikan pada tabel 1 sebagai berikut:

Tabel 1. Skala Likert

\begin{tabular}{|c|c|}
\hline Skala Likert & Keterangan \\
\hline 1 & Sangat Tidak Setuju \\
\hline 2 & Tidak Setuju \\
\hline 3 & Setuju \\
\hline 4 & Sangat Setuju \\
\hline
\end{tabular}

\section{HASIL DAN PEMBAHASAN}

\subsection{Analisis Statistik Deskriptif}

Merupakan analisis yang digunakan dengan melakukan deskripsi data yang terkumpul tanpa bermaksud untuk membuat konklusi yang lebih jauh dari data yang ada [10]. Hasil perhitungan analisis statistik deskriptif pada tabel 2 sebagai berikut:

Tabel 2. Analisis Statistik Deskriptif

\begin{tabular}{|c|c|c|c|}
\hline Item & Modus & Min & Max \\
\hline CON1 & 3,00 & 1,00 & 4,00 \\
\hline CON2 & 4,00 & 2,00 & 4,00 \\
\hline CON3 & 4,00 & 2,00 & 4,00 \\
\hline CON4 & 4,00 & 1,00 & 4,00 \\
\hline CON5 & 4,00 & 1,00 & 4,00 \\
\hline ACC1 & 3,00 & 1,00 & 4,00 \\
\hline ACC2 & 3,00 & 1,00 & 4,00 \\
\hline ACC3 & 4,00 & 1,00 & 4,00 \\
\hline ACC4 & 4,00 & 1,00 & 4,00 \\
\hline
\end{tabular}




\begin{tabular}{|c|c|c|c|}
\hline FOR1 & 3,00 & 1,00 & 4,00 \\
\hline FOR2 & 3,00 & 1,00 & 4,00 \\
\hline FOR3 & 4,00 & 1,00 & 4,00 \\
\hline FOR4 & 4,00 & 1,00 & 4,00 \\
\hline EOU1 & 3,00 & 1,00 & 4,00 \\
\hline EOU2 & 4,00 & 1,00 & 4,00 \\
\hline EOU3 & 4,00 & 1,00 & 4,00 \\
\hline EOU4 & 4,00 & 1,00 & 4,00 \\
\hline EOU5 & 3,00 & 1,00 & 4,00 \\
\hline TIM1 & 3,00 & 1,00 & 4,00 \\
\hline TIM2 & 3,00 & 1,00 & 4,00 \\
\hline TIM3 & 4,00 & 1,00 & 4,00 \\
\hline TIM4 & 3,00 & 1,00 & 4,00 \\
\hline EUS1 & 4,00 & 1,00 & 4,00 \\
\hline EUS2 & 3,00 & 1,00 & 4,00 \\
\hline EUS3 & 3,00 & 1,00 & 4,00 \\
\hline EUS4 & 3,00 & 1,00 & 4,00 \\
\hline
\end{tabular}

\subsection{Analisis Outer dan Inner Model}

Evaluasi Pengukuran Model (Outer Model) merupakan langkah pengujian terhadap korelasi hubungan antara variabel laten dengan indikatornya [9]. Untuk melakukan analisis outer model perlu untuk melakukan uji validitas dan reliabilitas. Berikut rule of thumb pada analisis convergent validity menurut [13] pada tabel 3 sebagai berikut:

Tabel 3. Rule of Thumb Convergent Validity

\begin{tabular}{|c|c|l|}
\hline Uji Validitas & Pengujian & \multicolumn{1}{c|}{ Rule of Thumb } \\
\hline $\begin{array}{c}\text { Convergent } \\
\text { Validity }\end{array}$ & Outer Loading & $>0,7$ nilai indikator yang mengukur variabel \\
& & tersebut dikatakan valid \\
\cline { 2 - 3 } & $\begin{array}{c}\text { Average Variance } \\
\text { Extracted (AVE) }\end{array}$ & $\begin{array}{l}>0,5 \text { nilai yang mengukur variabel tersebut } \\
\text { dikatakan valid }\end{array}$ \\
& & \\
\hline
\end{tabular}

\subsubsection{Outer Loading}

Merupakan analisis yang digunakan untuk mengukur keabsahan atau tidaknya variabel dan masing-masing indikator pada penelitian. Hasil perhitungan analisis pada tabel 4 sebagai berikut:

Tabel 4. Uji Validitas Outer Loading

\begin{tabular}{|c|c|c|c|}
\hline Variabel & Indikator & Outer Loading & Keterangan \\
\hline \multirow{4}{*}{ Content (Isi) } & CON1 & 0,775 & Valid \\
\cline { 2 - 4 } & CON2 & 0,752 & Valid \\
\cline { 2 - 4 } & CON3 & 0,760 & Valid \\
\cline { 2 - 4 } & CON4 & 0,817 & Valid \\
\cline { 2 - 4 } & CON5 & 0,794 & Valid \\
\hline
\end{tabular}




\begin{tabular}{|c|c|c|c|}
\hline \multirow{4}{*}{ Accuracy (Keakuratan) } & ACC1 & 0,782 & Valid \\
\cline { 2 - 4 } & ACC2 & 0,770 & Valid \\
\cline { 2 - 4 } & ACC3 & 0,715 & Valid \\
\cline { 2 - 4 } & ACC4 & 0,829 & Valid \\
\hline \multirow{4}{*}{ Format (Bentuk) } & FOR1 & 0,812 & Valid \\
\cline { 2 - 4 } & FOR2 & 0,842 & Valid \\
\cline { 2 - 4 } & FOR3 & 0,830 & Valid \\
\cline { 2 - 4 } & FOR4 & 0,843 & Valid \\
\hline \multirow{4}{*}{$\begin{array}{c}\text { Ease of Use (Kemudahan } \\
\text { Penggunaan) }\end{array}$} & EOU1 & 0,886 & Valid \\
\cline { 2 - 4 } & EOU2 & 0,899 & Valid \\
\cline { 2 - 4 } & EOU3 & 0,895 & Valid \\
\cline { 2 - 4 } & EOU4 & 0,907 & Valid \\
\hline \multirow{4}{*}{ Timeliness (Ketepatan waktu) } & TIM1 & 0,841 & Valid \\
\cline { 2 - 4 } & TIM2 & 0,813 & Valid \\
\cline { 2 - 4 } & TIM3 & 0,722 & Valid \\
\cline { 2 - 4 } & TIM4 & 0,757 & Valid \\
\hline End-User Satisfaction (Kepuasan & EUS1 & 0,784 & Valid \\
\cline { 2 - 4 } Pengguna) & EUS2 & 0,847 & Valid \\
\cline { 2 - 4 } & EUS3 & 0,868 & Valid \\
\cline { 2 - 4 } & EUS4 & 0,797 & Valid \\
\hline
\end{tabular}

\subsubsection{AVE}

Merupakan analisis untuk mengukur keabsahan atau tidaknya variabel pada penelitian, dan memastikan hasil analisis outer loading sebelumnya. Hasil perhitungan analisis pada tabel 5 sebagai berikut:

Tabel 5. Uji Validitas AVE

\begin{tabular}{|c|c|c|}
\hline Variabel & AVE & Keterangan \\
\hline Content (Isi) & 0,608 & Valid \\
\hline Accuracy (Keakuratan) & 0,601 & Valid \\
\hline Format (Bentuk) & 0,692 & Valid \\
\hline Ease of Use (Kemudahan Penggunaan) & 0,804 & Valid \\
\hline Timeliness (Ketepatan waktu) & 0,616 & Valid \\
\hline End-User Satisfaction (Kepuasan Pengguna) & 0,680 & Valid \\
\hline
\end{tabular}

Masih pada tahap pengujian validitas, berikut rule of thumb pada analisis discriminant validity menurut [13] pada tabel 6 sebagai berikut:

Tabel 6. Rule of Thumb Discriminant Validity

\begin{tabular}{|c|c|l|}
\hline Uji Validitas & Pengujian & \multicolumn{1}{|c|}{ Rule of Thumb } \\
\hline $\begin{array}{c}\text { Discriminant } \\
\text { Validity }\end{array}$ & $\begin{array}{c}\text { Fornell Lacker } \\
\text { Criterion }\end{array}$ & $\begin{array}{l}\text { Nilai korelasi antara satu variabel dengan } \\
\text { variabel itu sendiri dengan variabel lainnya } \\
\text { harus lebih tinggi agar dikatakan valid }\end{array}$ \\
\cline { 2 - 4 } & Cross Loading & $\begin{array}{l}>0,7 \text { nilai dalam satu variabel atau korelasi } \\
\text { antara variabel dengan indicator variabel itu } \\
\text { sendiri dengan indikator variabel lainnya harus } \\
\text { lebih tinggi agar dikatakan valid }\end{array}$ \\
\hline
\end{tabular}




\subsubsection{Fornell Lacker Criterion}

Uji validitas fornell lacker criterion untuk semua variabel dinyatakan valid karena masing-masing variabel memiliki nilai pengukuran variabel dengan variabel itu sendiri lebih besar dari pengukuran nilai variabel dengan variabel lainnya.

\subsubsection{Cross Loading}

Uji validitas cross loading dinyatakan valid karena masing-masing indikator variabel memiliki nilai pengukuran indikator variabel dengan variabel itu sendiri lebih besar dari pengukuran nilai indikator variabel dengan variabel lainnya. Selanjutnya, uji reliabilitas untuk menunjukkan nilai keandalan dan konsistendi dari indikator yang terdapat pada variabel. Berikut rule of thumb pada analisis reliabilitas menurut [13] pada tabel 7 sebagai berikut:

Tabel 7. Rule of Thumb Uji Reliabilitas

\begin{tabular}{|c|c|l|}
\hline Uji Reliabilitas & Pengujian & \multicolumn{1}{c|}{ Rule of Thumb } \\
\hline Reliability & $\begin{array}{c}\text { Cronbach's } \\
\text { Alpha }\end{array}$ & $\begin{array}{l}>0,7 \text { nilai yang mengukur variabel tersebut } \\
\text { dikatakan reliabel }\end{array}$ \\
& & \\
\cline { 2 - 3 } & $\begin{array}{c}\text { Composite } \\
\text { Reliability }\end{array}$ & $\begin{array}{l}>0,7 \text { nilai yang mengukur variabel tersebut } \\
\text { dikatakan reliabel }\end{array}$ \\
\hline
\end{tabular}

\subsubsection{Cronbach's Alpha}

Merupakan analisis untuk mengukur kredibilitas variabel pada penelitian. Hasil perhitungan analisis pada tabel 8 sebagai berikut:

Tabel 8. Uji Reliabilitas Cronbach's Alpha

\begin{tabular}{|c|c|c|}
\hline Variabel & Cronbach's Alpha & Keterangan \\
\hline Content $(\mathrm{X} 1)$ & 0,839 & Reliabel \\
\hline Accuracy $(\mathrm{X} 2)$ & 0,779 & Reliabel \\
\hline Format $(\mathrm{X} 3)$ & 0,852 & Reliabel \\
\hline Ease of Use $(\mathrm{X} 4)$ & 0,919 & Reliabel \\
\hline Timeliness $(\mathrm{X} 5)$ & 0,791 & Reliabel \\
\hline End-User Satisfaction $(\mathrm{Y})$ & 0,842 & Reliabel \\
\hline
\end{tabular}

\subsubsection{Composite Reliability}

Sama seperti analisis yang dilakukan sebelumnya, untuk mengukur kredibilitas variabel pada penelitian. Hasil perhitungan analisis pada tabel 9 sebagai berikut:

Tabel 9. Uji Reliabilitas Composite Reliability

\begin{tabular}{|c|c|c|}
\hline Variabel & Composite Reliability & Keterangan \\
\hline Content $(\mathrm{X} 1)$ & 0,886 & Reliabel \\
\hline Accuracy $(\mathrm{X} 2)$ & 0,857 & Reliabel \\
\hline Format $(\mathrm{X} 3)$ & 0,900 & Reliabel \\
\hline Ease of Use $(\mathrm{X} 4)$ & 0,943 & Reliabel \\
\hline Timeliness $(\mathrm{X} 5)$ & 0,865 & Reliabel \\
\hline End-User Satisfaction $(\mathrm{Y})$ & 0,895 & Reliabel \\
\hline
\end{tabular}


Selanjutnya, Evaluasi Struktural Model (Inner Model) atau disebut dengan model struktural menggunakan $R$-Square sebagai pengukuran nilai yang hanya dimiliki oleh variabel $\mathrm{Y}$ atau variabel endogen. Kemudian, untuk mengukur variabel eksogen menggunakan nilai path coefficient dengan nilai signifikansinya berdasarkan nilai $t$-statistic.

\subsection{7 $R$-Square}

$R$-Square adalah nilai yang memperlihatkan seberapa besar variabel eksogen yang mempengaruhi variabel endogen. Didapatkan nilai pada tabel 10 uji $R$-Square yaitu 0,673 jika dikonversi ke presentase menjadi 67,3\%. Maka, dapat disimpulkan bahwa variabel End-User Satisfaction (variabel endogen) dipengaruhi sebesar 67,3\% oleh variabel eksogen.

Tabel 10.Uji R-Square

\begin{tabular}{|c|c|c|}
\hline & $R$-Square & $R$-Square Adjusted \\
\hline $\mathrm{Y}$ (End-User Satisfaction) & 0,673 & 0,664 \\
\hline
\end{tabular}

\subsubsection{Path Coefficients}

Uji path coefficients digunakan sebagai pengukuran nilai untuk menunjukkan arah hubungan yang negatif dengan range -1 sampai 0 atau positif dengan range 0 sampai 1 . Didapatkan nilai path coefficients pada tabel 11 yang berada diantara range 0 sampai 1 yang artinya positif.

Tabel 11. Uji Path Coefficients

\begin{tabular}{|c|c|}
\hline Variabel & End-User Satisfaction $(\mathrm{Y})$ \\
\hline Content $(\mathrm{X} 1)$ & 0,276 \\
\hline Accuracy $(\mathrm{X} 2)$ & 0,044 \\
\hline Format $(\mathrm{X} 3)$ & 0,134 \\
\hline Ease of Use $(\mathrm{X} 4)$ & 0,162 \\
\hline Timeliness $(\mathrm{X} 5)$ & 0,355 \\
\hline
\end{tabular}

\subsubsection{T-Statistics}

Uji $t$-statistics digunakan sebagai pengukuran nilai untuk menunjukkan hubungan yang signifikan. Ketentuan dari uji $t$-statistics ini nilai $t$-statistics lebih besar dari nilai $\mathrm{r}$ tabel untuk mendapatkan hasil yang signifikan. Syarat nilai 1,97 diambil dari perhitungan degrees of freedom $(\mathrm{df})=\mathrm{N}-2=205-2=203$ dan tingkat signifikansi untuk uji dua arah sebesar 0,05 . Hasil perhitungan analisis dapat dilihat pada tabel 12 sebagai berikut:

Tabel 12. Uji T-Statistics

\begin{tabular}{|c|c|}
\hline Variabel & T-Statistics \\
\hline Content $>$ End-User Satisfaction & 3,909 \\
\hline Accuracy $>$ End-User Satisfaction & 0,623 \\
\hline Format $>$ End-User Satisfaction & 1,717 \\
\hline Ease of Use $>$ End-User Satisfaction & 2,604 \\
\hline Timeliness $>$ End-User Satisfaction & 5,427 \\
\hline
\end{tabular}

\subsection{Pengujian Hipotesis}

Hasil pengujian hipotesis antar variabel eksogen dengan endogen dapat disajikan pada tabel 13 sebagai berikut: 
Tabel 13. Hasil Hipotesis

\begin{tabular}{|c|c|c|}
\hline \multicolumn{2}{|c|}{ Hipotesis } & Hasil \\
\hline H1 & CON > EUS & Diterima \\
\hline H2 & ACC > EUS & Ditolak \\
\hline H3 & FOR > EUS & Ditolak \\
\hline H4 & EOU > EUS & Diterima \\
\hline H5 & TIM $>$ EUS & Diterima \\
\hline
\end{tabular}

Hasil pengujian path coefficients dan t-statistics pada analisis struktural model menunjukkan bahwa $\mathrm{H} 1, \mathrm{H} 4$, dan $\mathrm{H} 5$ diterima, artinya variabel content, ease of use, dan timeliness memiliki pengaruh terhadap variabel end-user satisfaction pada sistem CeLOE LMS. Hal ini sesuai dengan asumsi peneliti dan dinyatakan bahwa mahasiswa aktif strata satu Universitas Telkom sangat setuju bahwa konten yang disajikan pada sistem CeLOE LMS menyediakan informasi yang tepat, berkualitas baik, disajikan secara jelas, membantu dalam memenuhi kebutuhan dalam menunjang kegiatan perkuliahan di masa pandemi COVID-19, dapat dengan mudah dioperasikan dan berinteraksi secara langsung dengan sistem, terdapat layanan menu bantuan, serta menyediakan data terkini.

Selanjutnya, hasil pengujian path coefficients dan $t$-statistics menunjukkan bahwa $\mathrm{H} 2$ dan H3 ditolak, artinya variabel accuracy, dan format tidak memiliki pengaruh terhadap variabel end-user satisfaction pada sistem CeLOE LMS. Hal ini dapat terjadi karena pada awal penerapan sistem CeLOE LMS masih banyak mata kuliah yang belum terdaftar pada sistem ataupun tidak tersedia meskipun telah tersinkronisasi, sehingga harus melakukan sinkronisasi ulang secara manual, dan masih banyak mahasiswa yang kesulitan dalam menggunakan sistem CeLOE LMS. Dengan kata lain, sistem CeLOE LMS belum menghasilkan informasi yang akurat dan terpercaya sepenuhnya, tampilan interface sistem CeLOE LMS belum menyediakan informasi dengan jelas, dan belum sepenuhnya mudah untuk digunakan serta dipahami user dalam menunjang kegiatan perkuliahan di masa pandemi COVID-19.

\section{KESIMPULAN}

Berdasarkan hasil analisis yang telah dilakukan, dapat disimpulkan bahwa:

1) Analisis tingkat kepuasan mahasiswa aktif program studi strata satu Universitas Telkom dalam menggunakan sistem CeLOE LMS dari total 205 sampel yang diambil, keseluruhan indikator nilai modus yang diperoleh kisaran angka sebesar 3,00 dan 4,00 dimana hal ini menunjukkan mahasiswa Universitas Telkom sangat setuju bahwa penggunaan sistem CeLOE LMS memiliki hasil yang positif dari segi konten, keakuratan informasi yang diberikan, kemudahan dalam penggunaan, tampilan interface, serta ketepatan waktu dalam penyajian informasi yang berpengaruh pada tingkat kepuasan mahasiswa dalam menunjang kegiatan perkuliahan di masa pandemi COVID-19.

2) Variabel yang mempengaruhi tingkat kepuasan mahasiswa terhadap model End-User Computing Satisfaction terdiri dari 5 variabel eksogen yaitu Content, Accuracy, Format, Ease of Use, dan Timeliness serta 1 variabel endogen yaitu End-User Satisfaction. Dari 5 hipotesis yang peneliti usulkan, terdapat 2 hipotesis yang hasilnya tidak signifikan terhadap variabel End-User Satisfaction (EUS) yaitu variabel Accuracy (ACC) dan variabel Format (FOR) karena nilai t-statistics berada dibawah 1,97. Sehingga, H2 dan H3 ditolak karena tidak terbukti. Sedangkan, 3 hipotesis lainnya terbukti positif dan signifikan karena memiliki nilai diatas 1,97. Sehingga, H1, H4, dan H5 diterima.

3) Rekomendasi yang diberikan untuk meningkatkan kepuasan pengguna sistem CeLOE LMS pada pihak manajemen CeLOE LMS yaitu dengan melakukan peningkatan layanan helpdesk 
secara berkala dan penyebaran kuesioner terhadap seluruh mahasiswa Universitas Telkom sesuai jumlah populasi untuk mendapatkan feedback yang lebih akurat.

\section{SARAN}

Berikut saran yang dapat peneliti ajukan, yaitu:

1) Diperlukan lebih banyak lagi responden yang terlibat agar hasil penelitian semakin valid dan semakin menggambarkan kondisi yang sebenarnya.

2) Penyebaran kuesioner perlu disiapkan secara matang agar penyebarannya tidak hanya di satu waktu saja sehingga dapat memperoleh sampel responden yang lebih banyak.

3) Model penelitian EUCS hanya berfokus pada kepuasan pengguna, untuk kedepannya mungkin bisa mengadopsi dengan model yang lain agar dapat melihat hasil penelitian dari perspektif yang lain.

\section{UCAPAN TERIMA KASIH}

Terima kasih kepada pihak pengelola CeLOE LMS Universitas Telkom yang telah bersedia untuk memenuhi wawancara dalam rangka pengumpulan data, serta kepada pihak kampus Universitas Telkom yang telah membantu dalam memberikan informasi berupa datadata pendukung yang berkaitan dengan penelitian.

\section{DAFTAR PUSTAKA}

[1] D. Handayani. 2020, “Jurnal Respirologi Indonesia: Penyakit Virus Corona 2019,” Vol. 40, No. 2, p. 128.

[2] A. Samudra. 2018, "Difusi Inovasi E-Learning (Studi Deskritif Kualitatif Tentang Inovasi E-learning SMA Batik 1 Surakarta)," Surakarta.

[3] A.-M. Tîrziu and C. Vrabie. 2015, "Education 2.0: E-Learning Methods," Procedia Soc. Behav. Sci., Vol. 186, pp. 376-380, doi: 10.1016/j.sbspro.2015.04.213.

[4] I. Wagimin, Patni Ninghardjanti, and Kristiani. 2014, "Model Kesuksesan Pembelajaran Dengan E-Learning Di Perguruan Tinggi," J. Penelit. Pendidik. Insa., Vol. 16, No. 1, pp. 23-35.

[5] Wijaya and Suwastika. 2017, "Analisis Kepuasan Pengguna Elearning Menggunakan Metode End-User Computing Satisfaction,” Konf. Nas. Sist. Inform. 2017, pp. 558-562.

[6] T. A. Prasetya and C. T. Harjanto. 2020, "Pengaruh Mutu Pembelajaran Online dan Tingkat Kepuasan Mahasiswa Terhadap Hasil Belajar Saat Pandemi Covid19," Pendidik. Teknol. dan Kejuru., Vol. 17, No. 2, pp. 188-197.

[7] P. Oktavia, 2016, “Penerapan Metode Servqual dan Metode Eucs Dalam Mengevaluasi Kepuasan Pelanggan dan Kualitas Layanan Teknologi Informasi Pengguna Jasa Internet Service Provider (Studi Kasus pada PT. Platinum Citra Indonesia, 
Tangerang),” J. Inform. Univ. Pamulang, Vol. 1, No. 2, pp. 69-79.

[8] D. Lestari. 2014, “Analisis Pengaruh Layanan E-Learning Be Smart Terhadap Kepuasan Pengguna Dengan Pendekatan Structural Equation Modeling (Studi Kasus: Mahasiswa Jurusan Pendidikan Matematika FMIPA UNY),” Yogyakarta.

[9] I. G. N. M. Jaya and I. M. Sumertajaya. 2008, "Pemodelan Persamaan Structural Dengan Partial Least Square,” Semnas Mat. dan Pendidik. Mat. 2008, pp. 118-132.

[10] Sugiyono. 2019, Metode Penelitian Kuantitatif, Kualitatif, dan R\&D, Alfabeta, Bandung.

[11] M. S. Muarie and F. Nopriani. 2020, "Mengukur Tingkat Kepuasan Pengguna ELearning (UIN Raden Fatah Palembang)," JUSIM (Jurnal Sist. Inf. Musirawas), Vol. 5, No. 01, pp. 79-86, doi: 10.32767/jusim.v5i01.756.

[12] N. L. A. K. Y. Sarja, 2018, “Pengukuran Kepuasan Pengguna Sistem Informasi Dosen Menggunakan Metode EUCS,” J. Sist. dan Inform., Vol. 12, No. 2, pp. 19-25.

[13] A. Sauddin and N. S. Ramadhani. 2018, “Analisis Pengaruh Keterampilan Mengajar, Emosi Mahasiswa, Tekanan Akademik dan Perceived Academic Control Terhadap Prestasi Akademik Mahasiswa Menggunakan Pendekatan Sem-Pls," J. Msa, Vol. 6, No. 1, pp. 6-12. 